\title{
PENERAPAN METODE INVESTIGASI KELOMPOK DALAM PEMBELAJARAN MENULIS TEKS EKSPLANASI MELALUI PENELITIAN TINDAKAN KELAS
}

\author{
Belinda Tri Ari Arva, Sumarwati, Sri Hastuti \\ Universitas Sebelas Maret \\ surel: belinda.taa@gmail.com
}

\begin{abstract}
The purpose of this study isto increase motivation and ability writetext explanation on student class XI A P 1 SMK N 1 Surakarta with apply method group investigation. This is classrrom action research which carried out in two cycles, each cycle consisting of planning, action, observation, and reflection. The results showed that through the application of methods group investigationcan increase motivation and potentiality write explanatory texts in class XI A P 1 SMK N 1 Surakarta from action practice to the first cycle and from the first cycle to the second cycle. Motivation students and in ability to write explanation text increase although not optimal yet there are still some deficiencies both from the teacher and student factors and need to be improved by the second cycle. The conclusions are: (1) implementation method group investigation enhancing motivation on student, (2) application of group investigation methods enhancing the ability to write explanatory text on students with concrete steps taken.
\end{abstract}

Keyword: motivation, explanation text, investigation group.

ABSTRAK: Tujuan penelitian ini adalah untuk meningkatkan motivasi dan kemampuan menulis teks eksplanasi pada siswa kelas XI AP 1 SMK N 1 Surakarta dengan menerapkan metode investigasi kelompok. Penelitian ini merupakan penelitian tindakan kelas. Penelitian dilaksanakan dalam dua siklus, tiap siklus terdiri atas perencanaan, pelaksanaan tindakan, observasi, dan refleksi. Hasil penelitian menunjukkan bahwa melalui penerapan metode investigasi kelompok dapat meningkatkan motivasi dan kemampuan menulis teks eksplanasi pada siswa kelas XI AP 1 SMK N 1 Surakarta dari pratindakan ke siklus I dan dari siklus I ke siklus II.Pembelajaran pada pratindakan bersifat teacher-centered (pembelajaran yang berpusat pada guru) sehingga motivasi siswa dan kemampuan menulis teks eksplanasi siswa kelas XI AP 1 SMK Negeri 1 Surakarta rendah. Peningkatan terjadi pada siklus I. Motivasi siswa dan kemampuan menulis teks eksplanasi siswa meningkat walaupun belum optimal masih ada beberapa kekurangan baik dari faktor guru maupun siswa dan perlu diperbaiki dengan dilaksanakannya siklus II. Simpulan penelitian ini yaitu: (1) penerapan metode investigasi kelompok meningkatkan motivasi dan kemampuan menulis teks eksplanasi pada siswa.

Kata kunci: motivasi, teks eksplanasi, metode investigasi kelas

BASASTRA Jurnal Bahasa, Sastra, dan Pengajarannya 


\section{PENDAHULUAN}

Pada Kurikulum 2013 mata pelajaran Bahasa Indonesia kelas XI, kompetensi dasar menulis yang tercantum adalah kompetensi dasar memproduksi teks eksplanasi kompleks yang koheren sesuai dengan karakteristik yang akan dibuat baik secara lisan maupun tulisan. Berdasarkan keterangan di atas, dapat disimpulkan bahwa siswa SMK kelas XI harus bisa menulis teks eksplanasi secara tepat dan dapat diterima.Keterampilan menulis yang tidak diimbangi dengan praktik menjadi satu faktor kurang terampilnya siswa dalam menulis.Siswa tingkat menengah atas baik SMA maupun SMK seharusnya sudah lebih baik untuk mengekspresikan gagasan, pikiran, dan perasaannya secara tertulis.

Suparno dan M. Yunus (2003: 3), menulis dapat didefinisikan sebagai suatu kegiatan penyampaian pesan (komunikasi) dengan menggunakan bahasa tulis sebagai alat medianya.Menulis juga sebagai sarana komunikasi seseorang selain berbicara.Dengan tulisan, seseorang dapat menyampaikan ide, gagasan, informasi yang lebih rinci dan skematis sesuai dengan kaidah berbahasa yang berlaku.Senada dengan salah satu fungsi menulis yang disampaikan diatas, Lawrence (dalam Slamet 2009 : 97) menyatakan bahwa menulis adalah mengkomunikasikan apa dan bagaimana pikiran penulis. Dengan menulis ide atau pikiran penulis dapat tersampaikan kepada pembaca.Menulis sebagai sarana komunikasi selain keterampilan berbicara. Seorang penulis tidak akanmengkomunikasikan secara langsung kepada pembacanya dengan bertatap muka, karena itu akan menghabiskan banyak waktu dan biaya. Jadi penulis berusaha menuangkan pikiran atau ide dalam sebuah tulisan sehingga semua pembaca dari berbagai tempat dapat menikmati dan mengetahui pikiran atau ide dari penulis tersebut.Begitu pentingnya menulis dalam kehidupan saat ini mendorong seseorang untuk belajar menulis sejak dari kecil.

Berdasarkan wawancara dengan guru, bahwa selama ini kemampuan menulis teks eksplanasi siswa belum dapat dicapai secara maksimal. Hal ini juga didukung dari hasil penelitian Novita Andyani yang berjudul Peningkatan Keterampilan Menulis Teks Eksplanasi dengan Menggunakan Media Audiovisual pada Siswa Sekolah Menengah Pertama.Dalam penelitian tersebut dipaparkan bahwa kemampuan menulis teks eksplanasi siswa masih rendah.Siswa masih mengalami kesulitan dalam menuangkan gagasan, minimnya penguasaan kosakata.Hal ini disebabkan oleh pembelajaran yang dilakukan guru tidak menarik dan memotivasi siswa saat pembelajaran.Karna metode yang digunakan berupa metode ceramah dan penugasan kepada siswa untuk berdiskusi dengan media pembelajaran seadanya.Hal tersebut menimbulkan kejenuhan siswa yang mengakibatkan siswa menjadi kurang konsentrasi sehingga materi tidak tersampaikan dengan baik kepada siswa. Dengan kata lain membuat motivasi siswa menurun. Tetapi setelah dibantu dengan inovasi yang baru sehingga kemampuan menulis teks eksplanasi siswa meningkat.

Motivasi dan belajar merupakan dua hal yang saling memengaruhi.Menurut B. Uno (2007: 23) menyatakan bahwa motivasi belajar adalah dorongan internal dan eksternal pada siswa-siswa yang sedang belajar untuk mengadakan perubahan tingkah laku, pada umumnya dengan beberapa indikator atau unsur yang mendukung. Melalui

BASASTRA Jurnal Bahasa, Sastra, dan Pengajarannya 
pendapat tersebut dapat disimpulkan bahwa motivasi belajar merupakan faktor psikis yang bersifat non-intelektual.Peranannya yang khas adalah dalam hal penumbuhan gairah, merasa senang dan semangat untuk belajar. Siswa yang memiliki motivasi, akan mempunyai banyak energi untuk melakukan kegiatan belajar. Hal senada disampaikan oleh Sardiman (2004: 75), menyatakan dalam kegiatan belajar, motivasi dapat dikatakan sebagai keseluruhan daya penggerak di dalam diri siswa yang menimbulkan kegiatan belajar, yang menjamin kelangsungan dari kegiatan belajar dan yang memberikan arah pada kegiatan belajar, sehingga tujuan yang dikehendaki oleh subjek belajar itu dapat tercapai. Jadi motivasi sangat penting dalam diri siswa untuk kelangsungan dalam pembelajaran.Berdasarkan hasil wawancara dengan siswa, siswa merasa kesulitan dalam menulis.Siswa mengalami kebuntuan ide atau gagasan sehingga tidak dapat menuangkannya dalam bentuk tulisan.Secara individu siswa juga merasa kurang percaya diri dalam menyampaikan gagasan.Hal ini perlu dibantu dengan belajar secara berkelompok.

Mahsun (2014: 33) mengungkapkan bahwa teks eksplanasi kompleks memiliki fungsi sosial menjelaskan atau menganalisis proses muncul atau terjadinya sesuatu. Oleh karena itu, teks ini memiliki struktur berpikir: judul, pernyataan umum, deretan penjelas (penjelas I, II, III, IV, dan seterusnya), dan interpretasi. Keseluruhan struktur teks ekplanasi kompleks diikat oleh piranti yang berupa pengulangan atau repetisi, misalnya pengulangan kosntruksi "... api abadi..." yang selalu muncul pada setiap paragraf pengisi struktur teks.

Banyak fakta-fakta, peristiwa-peristiwa, hasil-hasil observasi dan dokumendokumen yang penting yang dapat dijadikan bahan dalam sebuah tulisan teks eksplanasi. Seseorang yang menulis teks eksplanasi melakukan pertalian antara berbagai macam fakta dan gagasan sehingga apa yang dikemukakannya itu terlihat logis dan kritis. Artinya teks eksplanasi dalam penulisannya benar-benar akurat dan semua berdasarkan fakta.Dalam mengatasi kesulitan menulis teks eksplanasi siswa kelas XIAP 1.Peneliti mencoba menerapkan metode investigasi kelompok. Investigasi adalah sebuah bentuk pembelajaran kooperatif yang berasal dari zaman John Dewey (Slavin, 2008 : 214).

Investigasi kelompok sesuai untuk studi yang terintegrasi yang berhubungan dengan hal-hal semacam penguasaan, analisis, dan mensistesiskan informasi sehubungan dengan upaya menyelesaikan masalah yang bersifat multi aspek.Terkait dengan penelitian diatas dapat dipaparkan penelitian-penelitian yang relevan. Penelitian yang ditulis oleh Aprisca Tri Wulandari menyajikan bahwa metode investigasi kelompok dapat meningkatkan kompetensi menulis argumentasi. Penelitian yang ditulis oleh Anggun Melati Sari menyajikan informasi mengenai siswa yang masih mengalami kesulitan dalam menulis teks eksplanasikompleks hal itu disebabkan oleh beberapa faktor antara lain tidak adanya bantuan bagi siswa untuk mengembangkan paragraf dari sebuah topik yang ada, proses pembelajaran masih menggunakan pendekatan konvensional, proses peembelajaran hanya berkisar penyampaian materi dengan ceramah sehingga siswa kurang mendapatkan praktik secara langsung.Penelitian Anggun Melati Sari memiliki kesamaan dengan penelitian 
yang akan dikaji. Melatih untuk bekerja secara kelompok memiliki kesamaan dengan penerapan model kooperatif. Komunikasi yang baik juga membantu dalam dunia kerja, hal ini selaras dengan subjek pada penelitian ini yaitu siswa SMK yang sejak di bangku sekolah sudah dipersiapkan untuk lulus dan langsung bekerja.

Berdasarkan penelitian di atas, terlihat jelas bahwa dalam kemampuan menulis diperlukan metode untuk dapat membantunya.Selain metode juga memerlukan motivasi siswa terkhusus untuk kemampuan menulis teks eksplanasi. Melatih siswa untuk memecahkan masalah secara bekerja sama membuat siswa dapat berkomunikasi di saat sudah memasuki dunia kerja.Berdasarkan latar belakang yang telah dipaparkan, peneliti berusaha memberikan solusi pemecahan masalah kepada guru yakni dengan menerapkan metode investigasi kelompok sebagai alat untuk meningkatkan motivasi dan kemampuan menulis teks eksplanasi pada siswa kelas XIAP 1 SMK Negeri 1 Surakarta.

\section{METODE PENELITIAN}

Penelitian ini dilaksanakan di SMK Negeri 1 Surakarta.Sekolah ini beralamat di jalan Kapuas No. 28 Surakarta.Penelitian ini dilaksanakan selama 6 bulan, yakni mulai bulan Desember 2015 sampai Mei 2016.Subjek penelitian ini adalah guru pengampu mata pelajaran Bahasa Indonesia dan para siswa kelas XIAdministrasi Perkantoran 1 SMK Negeri 1 Surakarta yang berjumlah 31 siswa. Penelitian ini berbentuk Penelitian Tindakan Kelas (Classroom Action Research). Data yang digunakan dalam penelitian ini adalah motivasi pembelajaran, informan atau narasumber, dokumen atau catatan lapangan hasil observasi. Teknik pengumpulan data yang digunakan dalam penelitian ini adalah sebagai berikut: observasi/pengamatan; wawancara mendalam; tes; dan analisis dokumen.

Untuk mengkaji validitas data, digunakan teknik triangulasi.Teknik trianggulasi yang digunakan dalam penelitian ini adalah trianggulasi sumber data dantrianggulasi metode.Teknik analisis data yang digunakan adalah teknik analisis deskripsi komparatif (statistik deskriptif komparatif).Untuk mengetahui penigkatan kemampuan siswa, peneliti menilai hasil pekerjaan siswa berdasarkan pedoman penilaian yang telah disepakai antara peneliti dan guru. Selanjutnya apabila penelitian ini telah mencapai kentuntasan sebesar $80 \%$ baik dalam motivasi dan hasil penulisan teks eksplanasi, maka penelitian akan dihentikan. Dalam pelaksanaan PTK ini, mekanisme kerjanya diwujudkan dalam bentuk siklus yang setiap siklusnya tercakup 4 kegiatan sebagai berikut : persiapan; pelaksanaan; observasi; dan refleksi.

\section{HASIL PENELITIAN DAN PEMBAHASAN}

Pembelajaran menulis teks eksplanasi dengan menggunakan metode investigasi kelompok ini dilaksanakan dalam 2 (dua) siklus, yaitu : siklus I dan siklus II. Berdasarkan pada hasil pengamatan dan analisis motivasi dan kemampuan menulis teks eksplanasi yang didasarkan pada serangkaian siklus tersebut, maka dapat dikatakan bahwa pembelajaran menulis teks eksplanasi dengan menggunakan metode

BASASTRA Jurnal Bahasa, Sastra, dan Pengajarannya 
investigasi kelompok siswa kelas XI AP 1 SMK Negeri 1 Surakarta mengalami peningkatan.

\section{Peningkatan Motivasi Menulis teks eksplanasi}

Peningkatan motivasi menulis teks eksplanasi siswa didasarkan pada penilaian yang memiliki indikator sebagai berikut : perhatian, semangat, dantanggung jawab. Pengamatan dilakukan sejak mulai prasiklus, siklus I dan siklus II. Secara umum skor motivasi menulis teks eksplanasi siswa mengalami peningkatan. Peningkatan motivasi ini dapat dilihat pada histogram berikut ini:

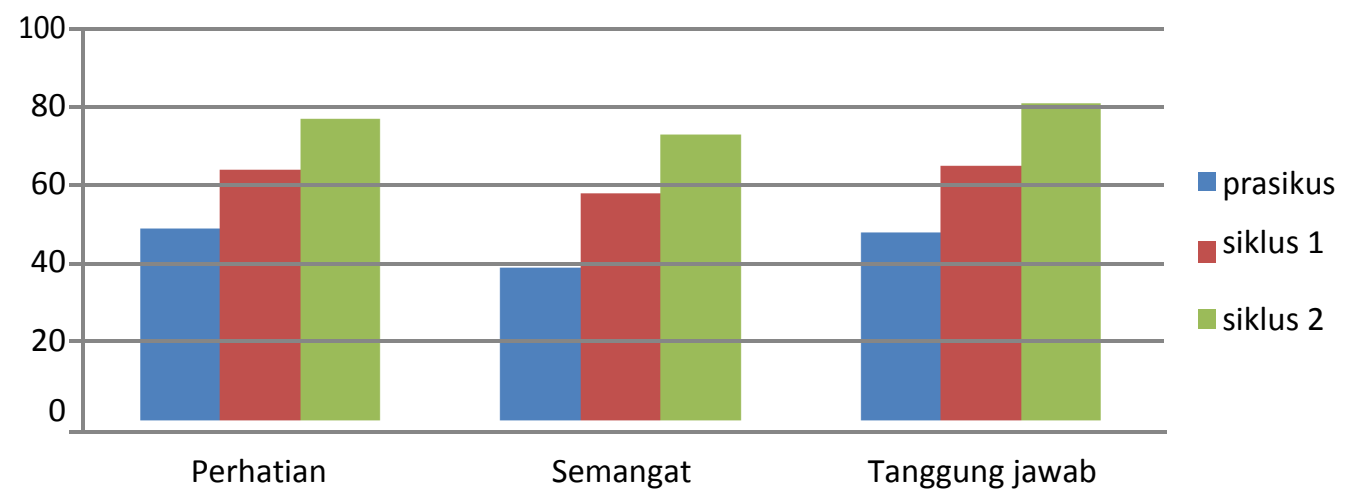

Diagram 1. Rekapitulasi Motivasi Menulis Teks Eksplanasi

Rata-rata nilai motivasi menulis teks eksplanasi mengalami kenaikan dari setiap siklusnya. Pada prasiklus nilai rata-rata mencapai 5,44, pada siklus 1 mencapai 7,48 , pada siklus 2 mencapai 8,59. Kenaikan rata-rata nilai motivasi menulis teks eksplanasi dapat dilihat pada diagram berikut:

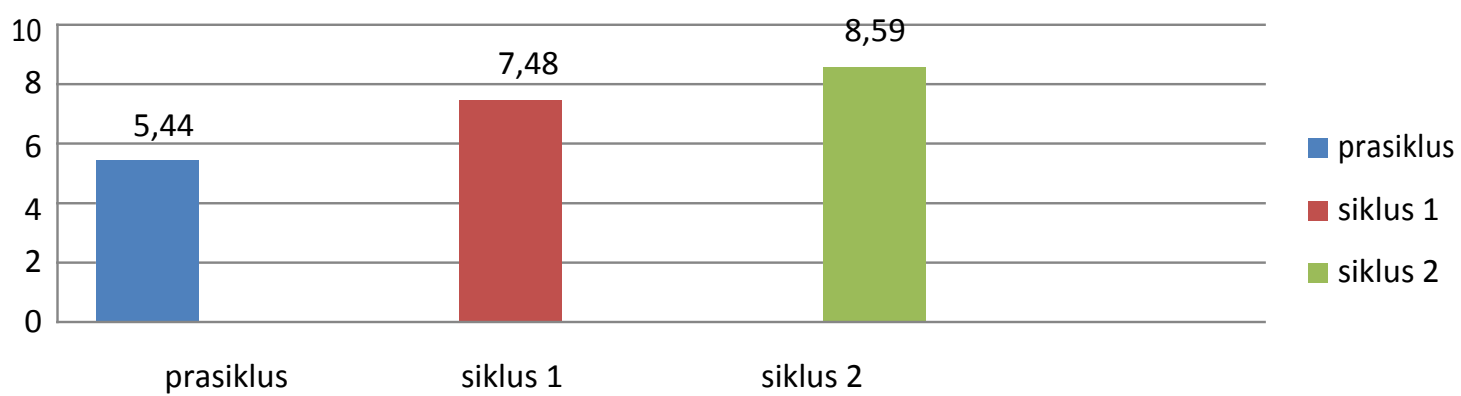

Diagram 2. Rekapitulasi Nilai Rata-rata Motivasi Menulis Teks Eksplanasi

Selain nilai rata-rata juga disajikan peningkatan prosentase pada setiap siklusnyaPada prasiklus prosentase motivasi siswa hanya 19\%, di siklus I meningkat menjadi $84 \%$, dan akhirnya pada siklus II meningkat lagi menjadi $92 \%$. 


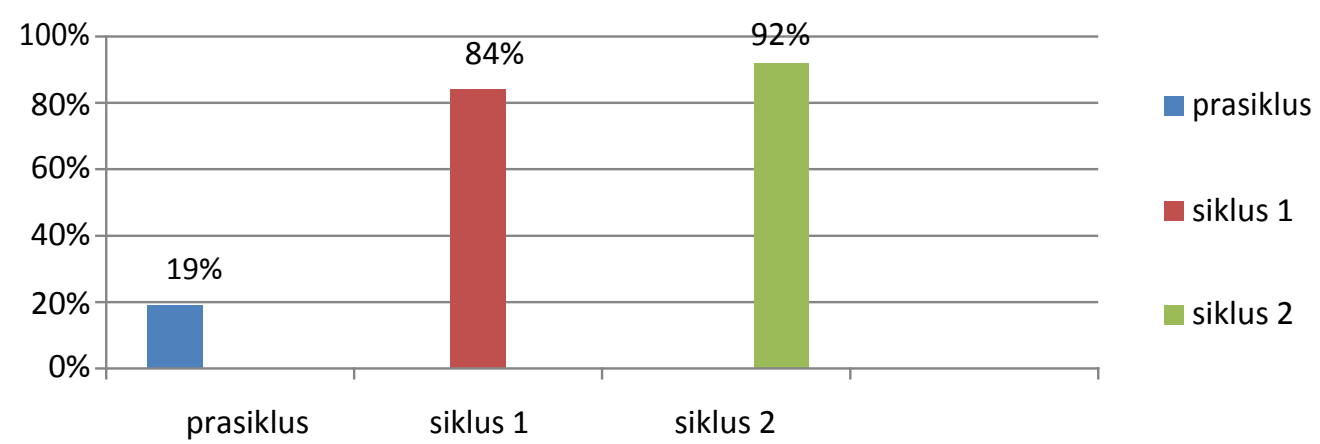

Diagram 3. Rekapitulasi Prosentase Motivasi Menulis Teks Eksplanasi

Peningkatan kemampuan menulis teks eksplanasi siswa didasarkan pada indikator: isi, organisasi isi, kosa kata, pengembangan bahasa, dan mekanik. Berdasarkan nilai akhir kemampuan menulis teks eksplanasi diketahui prosentase keberhasilan kemampuan menulis teks eksplanasi. Prosentase keberhasilan tersebut dapat dilihat pada tabel berikut:

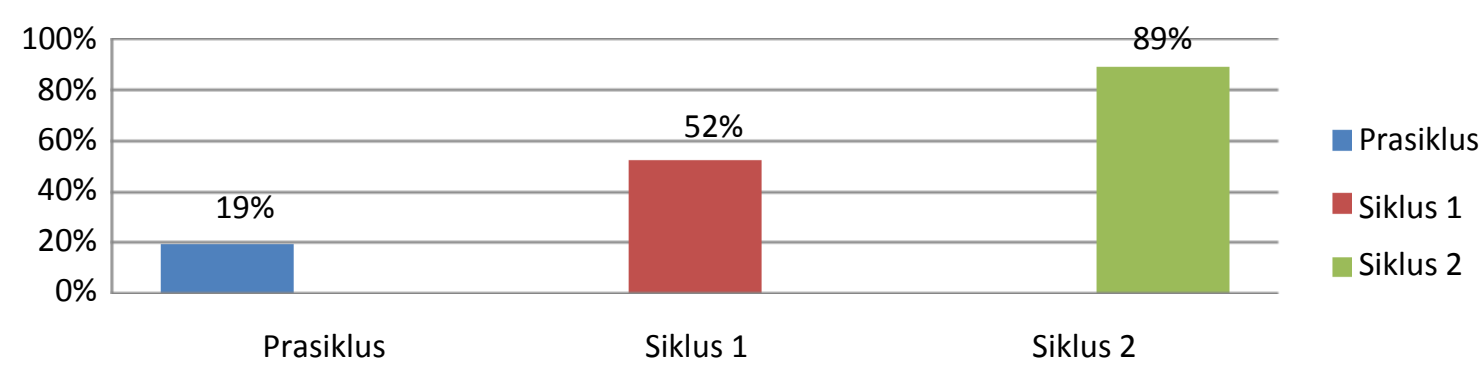

Diagram 4. Rekapitulasi Prosentase Keberhasilan Kemampuan Menulis Teks Eksplanasi

Rata-rata nilai kemampuan menulis teks eksplanasi mengalami kenaikan dari setiap siklusnya. Pada prasiklus nilai rata-rata mencapai 61,92, pada siklus 1 mencapai 70,8 dan pada siklus 2 mencapai 76,15. Kenaikan rata-rata nilai kemampuan menulis teks eksplanasi dapat dilihat pada diagram berikut:

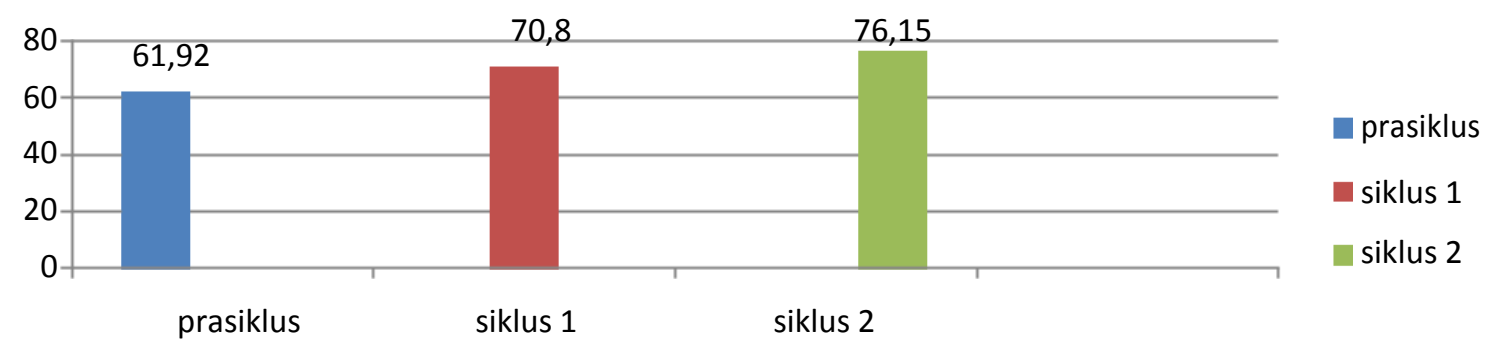

Diagram 4. Rekapitulasi Nilai Rata-rata Kemampuan Menulis Teks Eksplanasi 


\section{PEMBAHASAN}

Berdasarkan siklus Idan siklus II, guru berhasil melaksanakan pembelajaran menulis teks eksplanasi dengan menggunakan metode investigasi kelompok. Keberhasilan tersebut dapat terlihat pada motivasi siswa pada saat mengikuti pembelajaran yang meningkat dari setiap siklusnya. Selain itu, penelitian ini juga bermanfaat untuk meningkatkan kinerja guru supaya lebih efektif dan menarik di dalam kelas. Metode pembelajaran ini juga dapat dimanfaatkan oleh guru untuk menarik perhatian siswa sehingga siswa termotivasi khususnya dalam pembelajaran menulis argumentasi. Keberhasilan metode investigasi kelompok dalam meningkatkan motivasi dan hasil pembelajaran menulis teks eksplanasi dapat dilihat dari indikator-indikator yang telah dicapai oleh siswa.

\section{Perhatian siswa dalam mengikuti pelajaran menulis teks eksplanasi}

Dengan adanya metode pembelajaran investigasi kelompok dalam pembelajaran menulis teks eksplanasi akan dapat menumbuhkan rasa perhatian siswa dalam mengikuti pelajaran. Perhatian tinggi yang dimiliki siswa dapat mendorong siswa untuk cepat tanggap dalam menerima pelajaran sehingga dalam mengerjakan tugas akan lebih tepat waktu dan memiliki hasil yang baik. Hal ini didorong oleh rasa motivasi siswa yang tinggi. Dalam pembelajaran menulis teks eksplanasi dengan metode investigasi kelompok terdapat langkah yang menyebutkan untuk setiap anggota kelompok saling memberikan kontribusi dan melakukan diskusi bersama. Ini sejalan dengan temuan Sumarwati, bahwa bersama kelompoknya, siswa dalam mencari informasi dapat saling memberikan kontribusi sehingga hal itu dapat membuat waktu menjadi efisien karena setiap anggota kelompok saling mencari dan memberikan informasi (2013: 30). Setiap kelompok dapat berdiskusi bersama memecahkan masalah dan menganalisis permasalahan yang diberikan. Hal ini yang membuat siswa untuk dapat menyelesaikan tugas tepat waktu dan hasil yang baik karena dikerjakan dengan bersama-sama atau kelompok.

Setelah dilaksanakan siklus I masih terdapat banyak siswa yang kurang perhatian sehingga mengumpulkan tugas melebihi batas waktu yang ditentukan.Siswa kebanyakan minta perpanjangan waktu beberapa menit untuk menyelesaikan tugas yang diberikan. Siswa dalam mengerjakan tugas secara berkelompok masih sering berbicara hal yang lain diluar tugas yang diberikan. Guru hanya mendominasi beberapa kelompok sehingga tidak semua kelompok dapat dipantau. Tetapi permasalahan ini berangsur-angsur dapat teratasi dengan dilakukannya siklus II.Pada siklus II mengalami peningkatan dalam perhatian siswa dalam mengikuti pelajaran.Pada saat siswa mengerjakan tugas secara berkelompok terlihat sekali bahwa siswa mulai fokus membicarakan topik yang dibahas dalam pelajaran sehingga dalam mengerjakan tugas dapat cepat selesai.Setiap kelompok tidak lagi meminta tambahan waktu untuk mengerjakan tugas.Setiap kelompok selesai mengerjakan tugas sesuai dengan waktu yang diberikan.

BASASTRA Jurnal Bahasa, Sastra, dan Pengajarannya 
Dengan demikian dapat dikatakan bahwa melalui metode investigasi kelompok yang didalamnya terdapat langkah setiap anggota kelompok saling memberikan kontribusi dan diskusi bersama dapat membuat siswa lebih perhatian dalam mengikuti pelajaran.Maka dari itu dapat disimpulkan bahwa metode investigasi kelompok dapat menumbuhkan perhatian siswa dalam mengikuti pelajaran.

\section{Semangat Siswa dalam Pembelajaran Menulis Teks Eksplanasi}

Semangat siswa dalam pembelajaran menulis teks eksplanasi melalui metode investigasi kelompok mengalami peningkatan dari setiap siklusnya. Pada siklus I terlihat jelas rata-rata nilai semangat siswa mencapai 2,2 dan pada siklus II nilai ratarata semangat siswa meningkat menjadi 3,17. Dengan kata lain dari siklus I ke siklus II naik sebesar 0, 97 poin.

Semangat siswa dalam pembelajaran menulis teks eksplanasi melalui metode investigasi kelompok pada siklus I mengalami permasalahan karena saat guru memberikan tugas untuk menganalisis ada beberapa siswa yang mengeluh dan hanya meletakkan kepala di atas meja walaupun beberapa siswa terlihat semangat dengan mematuhi perintah guru tetapi itu belum menunjukkan peningkatan yang signifikan seperti yang diharapkan.Pada siklus II peningkatan semangat siswa sangat terlihat.Terlihat jelas saat siswa berdiskusi dan mengerjakan tugas sangat fokus dan ingin cepat segera menyelesaikan.Dalam metode investigasi kelompok terdapat langkah untuk presentasi. Pada saat presentasi setiap kelompok sangat bersemangat memaparkan hasil diskusi di depan guru dan teman lainnya untuk mendapatkan penilaian dan juga siswa berlomba-lomba untuk menunjukkan siapa yang lebih dahulu mempresentasikan hasil diskusi kelompok mereka. Pencarian informasi dan pengerjaan tugas secara berkelompok dapat menambah semangat siswa untuk mengerjakan tugas dari guru.Dalam pembelajaran menulis teks eksplanasi melalui metode investigasi kelompok juga mengharuskan guru untuk tidak terlalu mendominasi siswa jadi dalam siswa memahami materi dapat lebih bebas untuk berpikir kreatif secara berkelompok. Guru hanya sebentar menyampaikan materi untuk pengantar dan selanjutnya diserahkan kepada siswa untuk dianalis secara berkelompok.

Dengan demikian dapat dikatakan bahwa melalui metode investigasi kelompok dapat menumbuhkan dan meningkatkan semangat siswa dalam menulis teks eksplanasi.Siswa menjadi tidak bosan dalam menerima pelajaran karena metode pembelajaran yang digunakan guru sangattepat.Maka dari itu metode investigasi kelompok sangat tepat dalam menumbuhkan semangat siswa khususnya dalam pembelajaran menulis teks eksplanasi.

\section{Siswa Tanggung Jawab Dalam Mengerjakan Tugas}

Siswa tanggung jawab dalam mengerjakan tugas melalui metode investigasi kelompok mengalami peningkatan pada setiap siklusnya. Pada siklus I terlihat jelas rata-rata nilai tanggung jawab siswa dalam mengerjakan tugas adalah 2, 72 dan pada 
siklus II meningkat menjadi 3,52. Peningkatan ini menunjukkan bahwa didalam metode investigasi kelompok terdapat langkah-langkah yang dapat membuat siswa tanggung jawab dalam mengerjakan tugas.Didalam metode investigasi kelompok terdapat langkah-langkah pencarian informasi secara berkelompok sehingga menghasilkan hasil yang lebih baik.

Penyusunan kerangka karangan yang didasarkan pada kerja kelompok membuat karangan yang ditulis juga lebih baik.Tanggung jawab siswa dalam mengerjakan tugas dapat terlihat pada saat siswa mengerjakan tugas menganalisis secara berkelompok dan berlanjut membuat karangan eksplanasi secara mandiri.Nilai yang dihasilkan dari karangan siswa dapat menunjukkan tanggung jawab siswa dalam mengerjakan tugas.Pada siklus I tanggung jawab siswa dalam mengerjakan tugas mengalami sedikit permasalahan karena nilai rata-rata yang dihasilkan siswa masih banyak yang belum mencapai batas tuntas.Pada siklus I saat berkelompok dalam menganalisis dan membuat kerangka karangan siswa juga masih kurang bertanggung jawab sehingga karangan teks eksplanasi yang dihasilkannya pun tidak maksimal.Pada akhirnya di siklus II tanggung jawab siswa dalam mengerjakan tugas mengalami peningkatan kembali dengan dicapainya nilai rata-rata yang sudah menembus nilai ketuntasan.Permasalahan yang terjadi pada prasiklus dapat mulai teratasi pada siklus I dan siklus II.

Dengan demikian dapat dikatakan bahwa melalui metode investigasi kelompok dapat menumbuhkan dan meningkatkan tanggung jawab siswa dalam mengerjakan tugas menulis teks eksplanasi.Siswa menjadi tanggung jawab dalam mengerjakan tugas karena dianalisis secara berkelompok dan hasilnya dipresentasikan.Hasil analisis kelompok dapat dijadikan acuan untuk membuat karangan eksplanasi secara mandiri.Maka dari itu metode investigasi kelompok sangat tepat dalam menumbuhkan tanggung jawab siswa khususnya dalam mengerjakan tugas menulis teks eksplanasi.

Penerapan metode investigasi kelompok yang dilaksanakan dalam setiap siklus dapat meningkatkan motivasi menulis teks eksplanasi siswa. Nilai rata-rata motivasi menulis teks eksplanasi siswa mengalami kenaikan secara berangsur-angsur. Hal ini dapat dilihat pada hasil akhir di siklus I mencapai 7,48 dan pada siklus II mengalami kenaikan menjadi 8,59.

Peningkatan motivasi siswa dalam pembelajaran menulis teks eksplanasi juga berdampak pada kemampuan siswa dalam menulis teks eksplanasi. Kemampuan siswa dalam menulis teks eksplanasi mengalami peningkatan. Hal ini dapat dilihat dari hasil teks setiap siswa dari setiap siklus yang dibandingkan dengan nilai siswa saat prasiklus. Peningkatan tersebut dapat dilihat dari setiap indikator yang dikemukakan oleh Burhan Nurgiyantoro (2010 : 441-442), meliputi : isi, organisasi isi, kosa kata, pengembangan bahasa, dan mekanik. Walaupun dalam setiap indikator ada beberapa kesalahan antara lain:

BASASTRA Jurnal Bahasa, Sastra, dan Pengajarannya 
Isi

Siswa telah mampu menuangkan ide serta gagasan serta mengembangkannya ke dalam bentuk karangan dengan baik. Pengembangan isi menjadi lebih baik ini dikarenakan pada saat prasiklus siswa hanya langsung diminta untuk membuat karangan eksplanasi dan siswa belum memiliki gambaran tentang isi permasalahan yang akan ditulis. Siswa cenderung mengarang hanya beberapa baris saja dan katakata pun cenderung banyak yang diulang selain itu banyak karangan yang dibuat siswa antar paragraf tidak sinkron terlihat siswa asal comot dan tulis tanpa melihat keselarasan isi. Selain itu dengan adanya diskusi kelompok akan menambah pengetahuan siswa sehingga siswa sudah memiliki banyak informasi saat menulis karangan eksplanasi. Peningkatan pengungkapan gagasan atau isi ini ditunjukkan dengan nilai rata-rata yang diperoleh siswa. Pada prasiklus nilai rata-rata siswa adalah 20,24kemudian pada siklus I meningkat menjadi 21,96 dan akhirnya pada siklus II kembali meningkat menjadi 26,12.

a. Organisasi Isi

Berdasarkan hasil karangan siswa dalam setiap siklus diketahui bahwa siswa sudah dapat mengorganisasikan kalimat dalam paragraf. Dengan adanya pengorganisasian kalimat dengan baik maka pembaca akan lebih mudah memahami isi yang dituliskan oleh penulis.Peningkatan pengorganisasian isi dapat dilihat pada rata-rata nilai siswa di setiap siklusnya. Pada prasiklus nilai rata-rata siswa adalah 13,4kemudian meningkat pada siklus I menjadi 14,6 akhirnya pada siklus II meningkat kembali menjadi 16,56.

b.Kosa kata

Dengan karangan yang dihasilkan dapat disimpulkan bahwa siswa sudah mampu memanfaatkan waktu dengan baik.Hal ini terlihat pada hasil karangan eksplanasi siswa yang sudah menggunakan kosa kata yang lebih bervariasi.Dibandingkan pada saat prasiklus kosa kata yang digunakan siswa masih sedikit dan cenderung diulang-ulang tetapi setelah dilakukan tindakan pada siklus I dan siklus II maka kosa kata yang digunakan sudah lebih bervariasi.Peningkatan penggunaan kosa kata yang dilakukan siswa ini dapat dilihat dari nilai rata-rata yang diperoleh siswa selama tindakan. Awalnya nilai siswa pada prasiklus hanya 12,72 kemudian meningkat pada siklus I menjadi 14,56 dan akhirnya pada siklus II meningkat kembali menjadi 17,08.

c. Pengembangan Bahasa

Siswa sudah mampu mengembangkan bahasa dengan baik hal ini terlihat dari struktur kalimat yang digunakan dalam menyusun karangan eksplanasi.Pada prasiklus siswa belum mampu mengembangkan bahasa dengan baik, siswa belum mampu mengunakan kalimat secara efektif.Ketidakefektifan ini misalnya terdapat pada kalimat "paling banyak gunug-gunung".Hal tersebut menimbulkan kemubaziran kata sehingga kata yang ditulis tidak berguna.Kata gununggunungsebenarnya sudah mewakili banyak gunung, sehingga seharusnya kata yang digunakan "paling banyak gunung". Selain itu ada juga kalimat yang maknanya membingungkan atau kabur, seperti : Tanah longsor disebabkan oleh 
dua faktor yaitu pendorong dan faktor pemicu bisa juga disebabkan oleh faktor alamiah dan ulah manusia. Tanah longsor yang disebakan oleh faktor pendorong adalah tanah longsor yang mempengaruhi kondisi material tanah itu sendiri. Fakor alamiah yang mempengaruhi tanah longsor seperti erosi, gempabumi, gunung berapi, tata lahan, tanah yang kurang padat, batuan yang kurang kuat serta hujan yang besar. Dalam kalimat tersebut dapat membingungkan pembaca karena pada awal kalimat sudah dijelaskan faktor tanah longsor itu adalah faktor pendorong dan faktor pemicu tetapi pada paragraf selanjutnya dijelaskan faktornya adalah faktor alamiah dan ulah manusia dan dalam penjelasannya tidak lengkap sehingga membuat pembaca bingung. Tindakan pada siklus I dan II terjadi peningkatan dengan ditandai siswa sudah mampu mengembangkan kalimat dengan baik.Peningkatan pengembangan bahasa yang menjadi lebih baik ini ditandai dengan naiknya nilai rata-rata dari setiap siklusnya. Pada prasiklus nilai yang diperoleh siswa 13,08 kemudian pada siklus I menjadi 16,68 selanjutnya pada siklus II meningkat menjadi 19,12.

d.Mekanik

Kesalahan mekanik yang sering dilakukan adalah dalam hal ejaan.Dalam karangan sebelum dilakukan tindakan sering terjadi kesalahan, yakni (1) kesalahan yang berupa huruf besar, misalnya: disebabkan oleh Pemuaian Udara yang cepatdan dilalui oleh Loncatan bunga api Listrik.Pada kata kata seharusnya huruf "p" ditulis dengan huruf kecil. Kemudian pada kata udara seharusnya huruf "u" ditulis dengan huruf kecil dan pada kata loncatan dan listrik huruf "l" juga ditulis dengan huruf kecil. Sehingga penulisan yang benar adalah pemuaian, udara, loncatan,listrik.(2) kesalahan tanda baca khususnya koma dan titik, misalnya: Gempa merupakan faktor penyebab utamanya dari terjadinya tsunami, baik gempa tektonik maupun gempa vulkanik, yang disebakan oleh gunung meletus. Setelah kata vulkanik diakhiri dengan tanda koma dan diikuti kata yang, seharusnya setelah kata vulkanik tidak diakhiri dengan tanda baca apapun karena kata yang mengikuti selanjutnya adalah kata yangberarti penjelasan dari kata sebelumnya. Dengan demikian penulisannya menjadi: Gempa bumi merupakan faktor penyebab utamanya dari terjadinya tsunami, baik gempa tektonik maupun gempa vulkanik yang disebabkan oleh gunung meletus.(3) Kesalahan penulisan kata baku, misalnya: kata yang disingkat menjadi yg, kata tidak disingkat menjadi $t d k$, kata dapat sering disingkat menjadi $d p t$, kata ditengah-tengah sering disingkat menjadi ditengah ${ }^{I I}$. (4) Kesalahan dalam penulisan tulisan asing yang tidak ditulis miring atau digaris bawahi seperti penulisan "tidal wave" seharusnya ditulis Tidal Wave. (5) Kesalahan penulisan suhu seperti : temperatur udara tepat dibawah awan adalah $0 C$. Seharusnya setelah angka " 0 " diberi tanda "0" kecil diatas untuk menandakan itu adalah penulisan suhu. Sehingga penulisannya yang benar adalah :...dibawah awan adalah $0^{0}$ C.(6) Kesalahan penggunaan bahasa daerah dalam teks eksplanasi seperti : ...air laut membludak dengan disertai angin yang kencang yang menimbulkan gelombang tinggi... kata "membludak" adalah bahasa daerah seharusnya memnggunakan kata "meluap" sehingga bisa ditulis 
...air laut meluat dengan disertai angin yang kencang....(7) Kesalahan pembentukan kata, misalnya dalam penggunaan kata depan dan awalan. Penggunaan kata awalan siswa yang salah misalnya : pada kata di sebabkan. Seharusnya kata awalan di ditulis gabung dengan kata sebabkan. Jadi pembetulannya menjadi disebabkan. Walaupun demikian setelah dilakukan tindakan nilai rata-rata siswa dalam mekanik meningkat dari setiap siklusnya. Pada saat prasiklus nilai rata-rata siswa adalah 2,48 kemudian pada siklus I nilai siswa menjadi 3,00dan akhirnya pada siklus II meningkat menjadi 3,36.

Berdasarkan nilai teks eksplanasi pada saat prasiklus, kemampuan menulis teks eksplanasi siswa masih tergolong rendah. Hal ini terlihat dari nilai rata-rata yang diperoleh siswa. Pada prasiklus nilai rata-rata yang diperoleh siswa sebesar 61,92 kemudian meningkat pada siklus I menjadi 70,8 selanjutnya pada siklus II meningkat kembali menjadi 76,15. Hal ini menunjukkan bahwa metode investigasi kelompok dapat meningkatkan kemampuan menulis teks eksplanasi siswa.

\section{SIMPULAN}

Berdasarkan paparan pembahasan dapat disimpulkan, bahwa penerapan metode investigasi kelompok dapat meningkatkan motivasi siswa dalam pembelajaran menulis teks eksplanasi pada kelas XIAP 1 SMK Negeri 1 Surakarta. Secara keseluruhan peningkatan motivasi siswa dalam pembelajaran menulis teks eksplanasi pada prasiklus sebesar 19\%, siklus I naik menjadi $84 \%$,pada siklus II naik menjadi $92 \%$. Penerapan metode investigasi kelompok dapat meningkatkan kemampuan menulis teks eksplanasi siswa kelas XIAP I SMK Negeri 1 Surakarta. Secara keseluruhan, pada prasiklus siswa yang memperoleh nilai diatas batas kelulusan adalah sebesar mencapai 19\% kemudian ketuntasan siswa meningkat pada siklus I menjadi 52\%. Selanjutnya ketuntasan siswa meningkat pada siklus II menjadi $89 \%$.

\section{DAFTAR PUSTAKA}

Sardiman. A.M. 2004. Interaksi dan Motivasi Belajar-Mengajar. Jakarta: Raja Grafindo Persada.

Andyani, N., Saddhono K.,\& Mujyanto, Y. (2016). Peningkatan Kemampuan menulis Teks Eksplanasi dengan Menggunakan Media Audiovisual pada Siswa Sekolah Menengah Pertama. BASASTRA Jurnal Penelitian Bahasa \& Sastra Indonesia dan Pengajarannya, 2016 (4): 2.

Nurgiyantoro, Burhan. 2010. Penilaian Pembelajaran Bahasa Berbasis Kompetensi. Yogyakarta: BPFE.

Slamet, St. Y. 2008. Dasar-Dasar Keterampilan Berbahasa Indonesia. Surakarta: LPP UNS. 
Slavin, Robert E. 2008.Cooperative Learning (Teori, Riset, dan Praktik). Bandung: Nusa Media.

Sudjana, Nana. 2012. Penilaian Hasil Proses Belajar Mengajar. Bandung: PT Remaja Rosdakarya.

Sumarwati. (2013). Teknik Peer-correction dalam Pembelajaran Menulis untuk Meningkatkan Penguasaan Kaidah Bahasa Indonesia Siswa Sekolah Menengah. Jurnal Pedagogia, 16 (1), 24-32.

Suparno dan M. Yunus. 2003. Keterampilan Dasar Menulis. Jakarta: UT.

Sussane Taylor. 2002. An Investigation Into the Possibility of a Growing Trend in Cooperative Education: "Reverse Cooperative Education".Asia-Pacific Journal of Cooperative Education. Vol (3/2). Pp. 45-52.

Uno, Hamzah. B. 2007. Teori Motivasi dan Pengukurannya (Analisis di Bidang Pendidikan). Jakarta: Bumi Aksara.

Wahyu Budi Prasetyo. 2011. Peningkatan Keterampilan Menulis Argumentasi dengan Media Poster Melalui Metode Mind Map pada Siswa Kelas X G SMA Negeri 5 Magelang (Tesis) (UNES) 